\title{
PENGARUH TINGKAT HUTANG, ARUS KAS DAN AKRUAL TERHADAP PERSISTENSI LABA DENGAN CORPORATE GOVERNANCE SEBAGAI VARIABEL MODERATING \\ (Studi Empiris pada Perusahaan yang Terdaftar di BEI Tahun 2011-2015)
}

\author{
Linawati \\ Universitas Pamulang \\ elin.linawati79@gmail.com
}

\begin{abstract}
The purpose of this study was to examine the influence of leverage, cash flow operation and accrual to earning persistene moderated good corporate governance. This study used multiple regression methode. Samples are companies listed on the Jakarta Stock Exchange by taking a sample of 42 Manufacturing Companiesfrom 2011-2015. Sampling is done by using purposive sampling method. Test the above hypothesis used SPSS 21. The result of this research explained that the leverage negative significant affect on earning persistence, cash flow positive significant affect on earning persistence, and accrual has not negative affect onearning persistence. While the test resulted from Multipled Regresion Analysis methode showed that corporate governance is not moderation the effect of leverage, cahsflow, and accrual to earning persistence.
\end{abstract}

Keywords: earning persistence, leverage, cash flow, accrual corporate governance

\section{PENDAHULUAN}

Laporan keuangan yang merupakan media komunikasi antara pihak-pihak yang berkepentingan terhadap perusahaan. Para Investor dan Kreditor atau pengguna laporan keuangan lainnya menggunakan laba yang merupakan salah satu bagian dari laporan keuangan untuk mengevaluasi kinerja dan aktivitas ekonomi perusahaan, para pengguna laporan keuangan berharap laba yang dihasilkan oleh perusahaan merupakan laba yang mempunyai kualitas tinggi karena digunakan sebagai dasar untuk pengambilan keputusan.

Kualitas laba menjadi pusat perhatian bagi para pengguna laporan keuangan, kususnya bagi mereka yang mengharap kualitas laba yang tinggi. Bellovary et al (2005) dalam Surifah (2010) mendefinisikan kualitas laba sebagai kemampuan laba dalam merefleksikan kebenaran laba perusahaan dan membantu memprediksi laba mendatang, dengan mempertimbangkan stabilitas dan persistensi laba. Laba mendatang merupakan indikator kemampuan membayar deviden masa mendatang.

Laba yang diperoleh tidak hanya dilihat dari besar kecilnya tetapi kemampuan untuk mempertahankan laba tersebut juga harus mendapat perhatian 
atau yang lebih dikenal dengan persistensi laba. Persistensi laba merupakan indikator dari kualitas laba. Pengukuran persistensi laba masih berbeda-beda, secara umum persistensi laba sebagai salah satu proksi kualitas laba diukur dari slope coefficient regresi current earnings pada lagged earnings, sedangkan Dechow dan Dichev (2002) mengukur persistensi laba berdasarkan kualitas akrual, dimana kualitas akrual didefinisikan sebagai estimasi error dari hasil regresi modal kerja akrual

Laporan arus kas diduga dapat mempengaruhi persistensi laba. Arus kas merupakan bagian dari laporan keuangan perusahaan yang dapat dijadikan sebagai acuan bagi investor untuk menilai perkembangan perusahaan dan menjaga tingkat likuiditas perusahaan. Data arus kas merupakan indikator keuangan yang lebih baik karena arus kas relatif lebih sulit untuk dimanipulasi, semakin tinggi rasio aliran kas operasi terhadap laba bersih, maka semakin tinggi pula kualitas laba tersebut. Pengakuan akrual dalam laporan keuangan diduga dapat mempengaruhi persistensi laba. Semakin banyak akrual berarti semakin banyak estimasi dan error estimasi, dan karena itu persistensi laba akan semakin rendah. Tingkat hutang juga mempengaruhi persistensi laba. Semakin tinggi modal kerja yang didanai oleh hutang, makan akan semakin meningkat laba.

Dalam penelitian ini persistensi laba merupakan tindakan signaling, yang menurut Beaver (2002) dalam Sunarto (2009), manajemen menyajikan informasi keuangan khususnya laporan laba diharapkan dapat memberikan sinyal kemakmuran kepada investor atau pemegang saham. Corporate governance merupakan suatu nilai tambah untuk investor dalam menilai suatu perusahaan yang dapat meningkatkan kepercayaan investor kepada suatu perusahaan. Corporate governance dapat dijadikan sebagai ukuran apakah perusahan yang dijadikan sampel transparan atau tidak khususnya terhadap kreditor dan investor. Dengan adanya tata kelola perusahaan yang baik, diharapkan kualitas laporan keuangan akan dinilai dengan baik oleh investor. Dengan adanya corporate governance akan memperkuat hubungan hutang terhadap persistensi laba, besarnya leverage sebuah perusahaan akan meningkatkan persistensi laba dengan tujuan untuk mempertahankan kinerja yang baik di mata investor.

Motivasi penelitian ini adalah perekayasaan laba sering ditemukan dengan tujuan hanya untuk mewujudkan kualitas laba yang tinggi atau laba yang persisten untuk mempengaruhi keputusan investor dalam berinvestasi. Selain itu juga 
persistensi laba tidak dapat diteliti langsung namun diukur oleh beberapa proksi yang mempengaruhinya. Perbedaan penelitian ini dengan penelitian sebelumnya adalah pada penelitian ini menggunakan variabel corporate governance sebagai pemoderasi sedangkan penelitian sebelumnya corporate governance digunakan sebagai variabel bebas, serta menambahkan variabel akrual dan arus kas. Berdasarkan latar belakang, maka judul penelitian ini adalah pengaruh tingkat hutang, arus kas dan akrual terhadap persistensi laba dengan corporate governance sebagai variabel moderating.

\section{TELAAH LITERATUR DAN PENGEMBANGAN HIPOTESIS}

\section{Agency Teory dan Stewardship Teory}

Teori keagenan (agency theory) mengimplikasi adanya asimetri informasi antaramanajer sebagai agen dan pemilik (pemegang saham) sebagai prinsipal. Menurut Wolk et al (2003) dan Soppe et al (2009) dalam Linda dkk (2011) menyebutkan bahwa agency theory menggambarkan kerangka kerja untuk menganalisa pelaporan keuangan antara manager dan pemilik perusahaan. Laporan keuangan dijadikan dasar pengambilan keputusan ekonomis berbagai pihak yang berkepentingan atas perusahaan/suatu entitas (stakeholders).

Menurut Anton (2010) Stewardship Theory berangkat dari perpektif pemikiran akuntansi manajemen yang banyak didasari teori-teori psikologi dan sosiologi. Dalam pengelolaan Stewardship Theory pengelolaan organisasi difokuskan pada harmonisasi antara pemilik modal (principles) dengan pengelola modal (steward) dalam mencapai tujuan bersama.

\section{Persistensi Laba}

Definisi persistensi laba menurut Scott (2015) adalah revisi laba yang diharapkan dimasa mendatang (expected future earnings) yang diimplikasikan oleh inovasi laba tahun berjalan sehingga persistensi laba dilihat dari inovasi laba tahun. Persistensi laba merupakan ukuran yang menjelaskan kemampuan perusahaan untuk mempertahankan jumlah laba yang diperoleh saat ini sampai satu periode masa depan (Sloan, 1996). Persistensi laba menurut Sunarto (2010) merupakan laba yang mempunyai kemampuan sebagai indikator laba periode mendatang (future earnings) 
yang dihasilkan oleh perusahaan secara berulang-ulang (repetitive) dalam jangka panjang (sustainable). Laba dikatakan persisten, apabila laba saat ini dapat digunakan sebagai pengukur laba periode mendatang

\section{Corporate Governance}

Penerapan corporate governance diharapkan dapat meningkatkan nilai tambah bagi semua pihak yang berkepentingan (stakeholders) melalui beberapa tujuan yaitu, pertama meningkatkan efisiensi, efektifitas, dan kesinambungan suatu organisasi yang memberikan kontribusi kepada terciptanya kesejahteraan pemegang saham, pegawai dan stakeholders lainnya dan merupakan solusi yang elegan dalam menghadapi tantangan organisasi kedepan. Kedua, meningkatkan legitimasi organisasi yang dikelola dengan terbuka, adil, dan dapat dipertanggungjawabkan. Ketiga, mengakui dan melindungi hak dan kewajiban para share holders dan stakeholders.

Peraturan Menteri BUMN Nomor Per-01/MBU/2011 mendefinisikan good corporate governance adalah prinsip-prinsip yang mendasari suatu proses dan mekanisme pengelolaan perusahaan berlandaskan peraturan perundang-undangan dan etika berusaha. Menurut Herawati (2008) prinsip-prinsip corporate governance yang diterapkankan memberikan manfaat diantaranya yaitu: (1) meminimalkan agency costs dengan mengontrol konflik kepentingan yang mungkin terjadi antara prinsipal dengan agen; (2) meminimalkan cost of capital dengan menciptakan sinyal positif kepada para penyedia modal; (3) meningkatkan citra perusahaan; (4) meningkatkan nilai perusahaan yang dapat dilihat dari cost of capital yang rendah, dan (5) peningkatan kinerja keuangan dan persepsi stakeholder terhadap masa depan perusahaan yang lebih baik.

\section{Tingkat Hutang}

Menurut Sawir (2003) tingkat hutang (leverage) merupakan rasio yang menghitung seberapa jauh dana yang disediakan oleh kreditur juga sebagai rasio yang membandingkan total hutang terhadap keseluruhan aset suatu perusahaan. Apabila investor melihat sebuah perusahaan dengan aset yang tinggi namun resiko leverage yang tinggi pula, maka akan berpengaruh pada keputusan investor untuk berinvestasi pada perusahaan tersebut. Menurut 
(Subramanyam dan Wild, 2013) financial leverage merupakan penggunaan utang untuk meningkatkan laba.

\title{
Arus Kas
}

Menurut Pernyataan Standar Akuntansi Keuangan No. 2 (IAI, 2015), arus kas didefinisikan sebagai arus masuk dan arus keluar kas atau setara kas. Beberapa analis keuangan lebih tertarik mengaitkan arus kas operasi sebagai penentu atas persistensi laba karena aliran kas dianggap lebih persisten dibandingkan komponen akrual. Semakin tinggi rasio arus kas operasi terhadap laba bersih, maka semakin tinggi tingkat kualitas laba.

\begin{abstract}
Akrual
Menurut (Dechow dan Dichev, 2002), akrual adalah besaran pendapatan yang diakui pada saat hak kesatuan usaha timbul lantaran penyerahan barang ke pihak luar dan biaya diakui pada saat kewajiban timbul lantaran penggunaan sumber ekonomik yang melekat pada barang yang diserahkan tersebut.

Pengukuran akrual merupakan perbedaan laba dengan arus kas operasi. Makin besar perbedaannya, maka perbedaan itu disebabkan karena aspek akrual atau kebijakan akuntansi, sedangkan arus kas operasional hanya berasal dari transaksi kas riil. Makin tinggi nilai akrual menunjukkan adanya strategi menaikkan laba dan makin minus nilai akrual menunjukkan adanya strategi menurunkan laba
\end{abstract}

\section{Ukuran Perusahaan}

Ukuran perusahaan merupakan salah satu faktor yang menentukan kemampuan perusahaan dalam menghasilkan laba. Pada dasarnya ukuran perusahaan hanya terbagi dalam tiga kategori, yaitu perusahaan besar (large firm), perusahaan menengah (medium size), dan perusahaan kecil (small firm). Semakin besar perusahaan, semakin banyak informasi yang terkandung di dalamnya dan mempunyai kekuatan tersendiri dalam menghadapi masalah bisnis dan kemampuan perusahaan dalam menghasilkan laba tinggi karena didukung oleh asset yang besar 


\section{Skema Kerangka Konseptual}

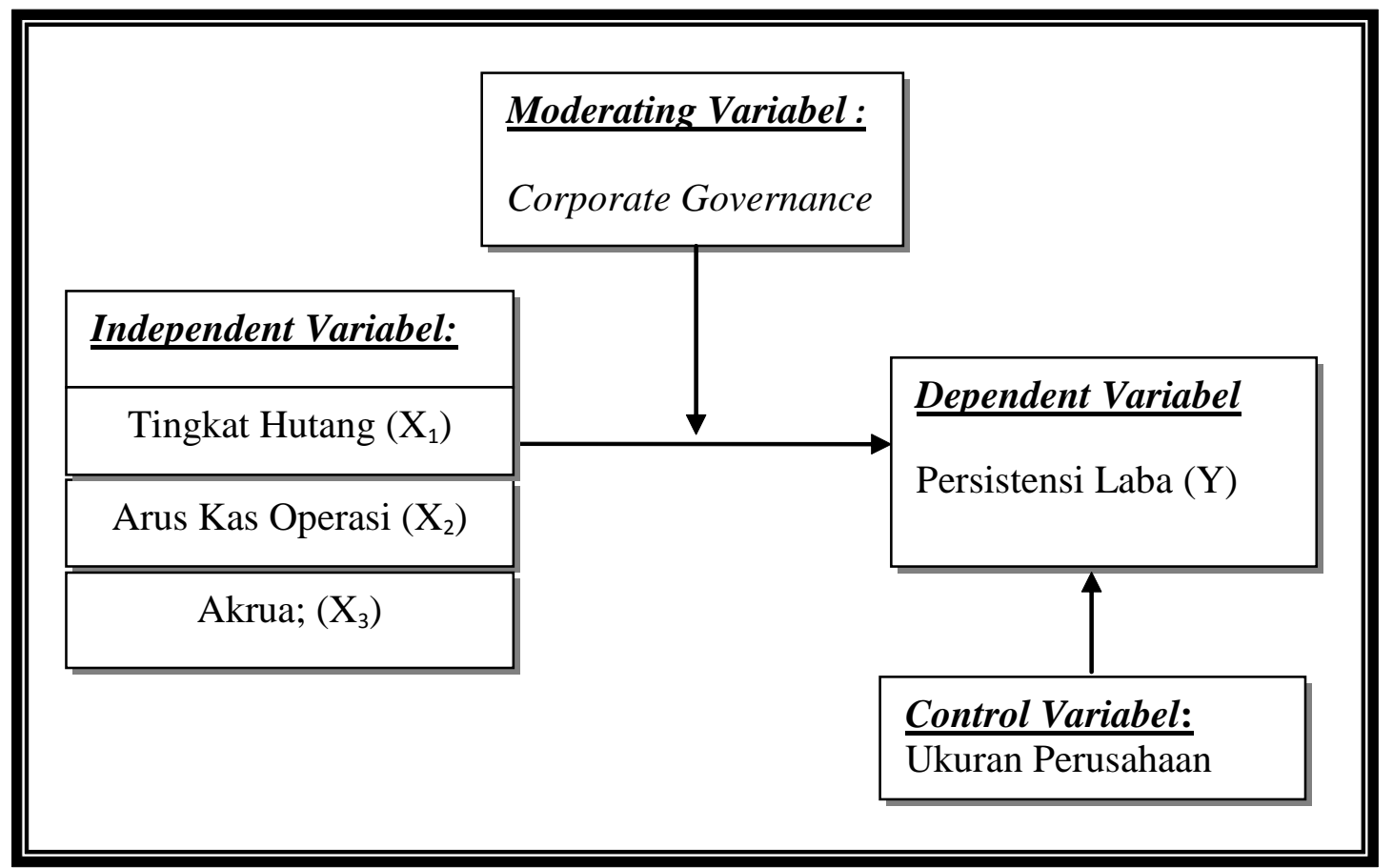

\section{Pengembangan Hipotesis}

\section{Pengaruh Tingkat Hutang Terhadap Persistensi Laba}

Rasio tingkat hutang ini merupakan perbandingan antara total hutang dan jumlah seluruh aktiva. Rasio ini menunjukkan berapa bagian dari keseluruhan aktiva yang dibelanjai oleh hutang. Semakin tinggi rasio ini berarti semakin besar jumlah modal pinjaman yang digunakan untuk investasi pada aktiva guna menghasilkan keuntungan bagi perusahaan.

\section{H1 : Tingkat hutang berpengaruh positif terhadap persistensi laba}

\section{Pengaruh Arus Kas Terhadap Persistensi Laba}

Semakin tinggi komponen arus kas akan meningkatkan persistensi laba yang dimiliki oleh perusahaan. Arus kas dari operasi menunjukkan kinerja operasi perusahaan dan kualitas laba yang dihasilkan. Makin tinggi arus kas operasi mengindikasikan bahwa perusahaan memberikan kinerja yang baik, dan diharapkan akan memberikan laba yang baik dimasa datang.

H2 : Arus kas operasi berpengaruh positif terhadap persistensi laba 


\section{Pengaruh Akrual Terhadap Persistensi Laba}

Laba akuntansi yang disajikan haruslah laba akuntansi yang persisten yaitu laba akuntansi yang tidak mengandung atau sedikit mengandung akrual sehingga dapat mencerminkan kinerja keuangan perusahaan yang sesungguhnya (Chandarin, 2003). Selain itu, penerapan konsep akrual merupakan salah satu peristiwa transitori yang menyebabkan laba mengalami gangguan. Pada akun-akun akrual tidak lepas dari adanya management judgement, sehingga tingkat subyektifitas yang ada pada satu akun berbeda dengan akun yang lainnya tergantung seberapa besar akun tersebut dipengaruhi oleh management judgement. Semakin besar akrual, maka persistensi laba semakin rendah.

\section{H3 : Akrual berpengaruh negatif terhadap persistensi laba}

\section{Pengaruh Corporate Governance sebagai Pemoderasi Hubungan Positif Antara}

\section{Tingkat Hutang Terhadap Persistensi Laba}

Rasio hutang tinggi dapat berarti baik, semakin tinggi tingkat hutang maka akan semakin baik kinerja perusahaan dimata investor. Perusahaan dalam melakukan ekspansi usaha lebih tertarik memperoleh modal melalui pinjaman salah satu kelebihannya karena biaya bunga pinjaman sebagai biaya tetap dapat dikurangkan sebagai pengurang pajak berbeda dengan dividen yang tidak dapat dikurangkan. Pengelolaan dana pinjaman dengan baik maka laba yang dihasilkan akan dapat menutup pembayaran bunga dan pokok pinjaman tersebut, tentunya pengelolaan yang transparan dan dapat dipertanggungjawabkan. Penerapan corporate governance dalam perusahaan diyakini mampu menciptakan kondisi perusahaan yang baik, menyajikan informasi yang berkulitas dan transparan terutama dalam pengelolaan hutang, sehingga membantu untuk para stakeholders dalam pengambilan keputusan.

H4 : Corporate Governance memperkuat hubungan positif antara tingkat hutang dan persistensi laba. 


\section{Pengaruh Corporate Governance sebagai Pemoderasi Hubungan Arus Kas terhadap Persistensi Laba}

Laba yang berkualitas adalah laba yang dapat mencerminkan kelanjutan laba (sustainable earnings) dimasa depan, yang ditentukan oleh komponen akrual dan kas dan dapat mencerminkan kinerja keuangan perusahaan yang sesungguhnya. Semakin besarnya komponen arus kas operasi dibandingkan akrual dalam lapoan laba maka laba tersebut akan bemakin berkutalitas. Penerapan Corporate Governance yang efektif akan bermanfaat bagi keberlanjutan perusahaan melalui kinerja keuangan yang baik, pertumbuhan bisnis dan komitmen dalam menerapkan praktik-praktik yang sehat. Perusahaan dapat mempertanggungjawabkan kinerja secara transparan sehingga perusahaan harus dikelola secara benar dan terukur terutama dalam mengelola arus kas dalam menghasilkan laba yang berkesinambungan.

\section{H5 : Corporate Governance memperkuat hubungan positif antara Arus Kas dan persistensi laba}

\section{Pengaruh Corporate Governance sebagai Pemoderasi Hubungan Akrual terhadap Persistensi Laba}

Akrual sering digunakan sebagai proksi manajemen laba oportunistik dalam beberapa penelitian sebelumnya sesuai dengan konteksnya masing-masing, tetapi manajer mungkin mempunyai motivasi lain untuk mencatat akrual yaitu untuk maksud pemberian sinyal mengenai kinerja perusahaan kini serta yang akan datang. Penerapan corporate governance dapat menunjukkan pengaruhnya terhadap penerapan penurunan tingkat rekayasa yang dilakukan manajemen. Pelaporan keuangan lebih transparan. Penelitian sebelumnya akrual berpengaruh negatif signifikan terhadap persistensi laba dibuktikan oleh Fanani (2010) dan Oei et all (2008). Mekanisme corporate governance yang baik diharapkan mampu mengurangi masalah keagenan yang akhirnya meningkatkan persistensi laba.

H6 : Corporate Governance memperlemah hubungan negatif antara akrual dan persistensi laba 


\section{METODE PENELITIAN DAN PEMBAHASAN}

Penelitian ini merupakan penelitian statistik deskriptif kuantitatif. Populasi diambil berdasarkan ICMD 2011-2015 dengan jumlah sampel sebesar 147 perusahaan manufaktur

\section{Operasional Variabel Dan Pengukurannya}

\section{Variabel dependen}

Menurut Penman dan Zhang (2002) mendefinisikan persistensi laba sebagai revisi laba yang diharapkan di masa mendatang (expected future earnings) yang diimplikasikan oleh inovasi laba tahun berjalan. Besarnya revisi ini menunjukkan tingkat persistensi laba.

Lipe (1990) dan Sloan (1996) dalam Wijayanti (2006) menggunakan koefisien regresi dari regresi antara laba akuntansi perioda sekarang dengan perioda yang akan datang sebagai proksi persistensi laba akuntansi. Laba akuntansi dianggap semakin persisten, jika koefisien variasinya semakin kecil. Proksi untuk mengukur persistensi laba dengan slope koefisien hasil regresi current earnings digunakan juga dalam penelitian yang dilakukan oleh Fanani (2009) dan Francis et al.(2004).

\section{Variabel Independen}

\section{Tingkat Hutang}

Tingkat hutang (leverage) yaitu perbandingan antara total hutang terhadap total aktiva. Rasio ini menekankan pentingnya pendanaan jangka panjang dengan jalan menunjukkan persentase aset perusahaan yang didukung oleh hutang. Tingkat hutang yang tinggi menunjukkan peningkatan dari resiko pada kreditor berupa ketidakmampuan perusahaan membayar hutang. Tingkat hutang yang tinggi juga akan mengakibatkan pembayaran bunga yang tinggi dan akhirnya berdampak pada tingkat pengembalian pada investor. 


\title{
Arus Kas Operasi
}

Komponen arus kas yang digunakan adalah arus kas operasi dengan metode langsung dari laporan arus kas. Arus kas operasi adalah arus kas yang berasal dari aktivitas penghasilan utama perusahaan.

\begin{abstract}
Akrual
Akrual yang merupakan selisih antara laba bersih dengan arus kas operasi. Laba akuntansi yang persisten adalah laba akuntansi yang memiliki sedikit atau tidak mengandung akrual dan dapat mencerminkan kinerja keuangan perusahaan yang sesungguhnya (Chandrarin, 2003). Semakin besar akrual yang terkandung dalam laba akuntansi, maka semakin rendah persistensi laba akuntansi.
\end{abstract}

\section{Variabel Moderasi}

\section{Good Corporate Governance}

Dalam penelitian ini diukur menggunakan instrument Asean Corporate Governance Scorecard (ACGS). Tahap perhitungan indeks pengungkapan ACGS yaitu:

a. Menyusun daftar (check list) item pengungkapan ACGS.

Daftar check list pengungkapan ACGS dalam penelitian ini menggunakan tabel scorecard yang dikembangkan oleh ASEAN Capital Market Forum (ACMF) yang dimulai pada tahun 2011 yang terdiri dari 5 tema yang dibagi menjadi 185 item pengungkapan dan digunakan untuk mengetahui seberapa jauh perusahaan mengungkapkan informasi mengenai Good Corporate Governance (GCG), bobot masing-masing tema sebagai berikut:
A. Hak Pemegang Saham
10\% (26 item pertanyaan)
B. Pendekatan Perataan pemegang Saham
$15 \%$ (17 item pertanyaan)
C. Peran Stakeholders
$10 \%$ (21 item pertanyaan)
D. Pengungkapan dan Transparansi
$25 \%$ (42 item pertanyaan)
E. Tanggungjawab Dewan
$40 \%$ (79 item pertanyaan)

Pada penelitian ini hanya menggunakan 121 item dari tema $\mathrm{D}$ dan tema $\mathrm{E}$ karena jumlah tema tersebut memiliki bobot yang paling besar dan memiliki bobot diatas $50 \%$ yang sudah dianggap mewakili seluruh pertanyaan pada $A C G S$. 
b. Menentukan Indeks Pengungkapan $G C G$

Pengungkapan GCG dalam check list menggunakan skor 1 untuk perusahaan yang mengungkapkan dan 0 jika tidak mengungkapkan. Kemudian skor tersebut dijumlahkan untuk mengetahui total pengungkapan GCG perusahaan

\section{Variabel Kontrol}

\section{Ukuran Perusahaan}

Variabel kontrol dalam penelitian ini adalah ukuran perusahaan, skala untuk mengukur besar kecilnya suatu perusahaan, biasanya untuk mengukur besar kecilnya perusahaan dapat dilihat dari besarnya aset atau total aktiva yang dimiliki perusahaan. semakin besar asset yang dimiliki perusahaan maka semakin besar ukuran perusahaan dan semakin kecilnya aset perusahaan maka ukuran perusahaan tersebut kecil.

\section{Pengukuran variabel}

\begin{tabular}{|c|c|c|}
\hline Variabel & Indikator & Skala \\
\hline $\begin{array}{l}\left(\mathrm{X}_{1}\right) \\
\text { Tingkat } \\
\text { Hutang }\end{array}$ & $\begin{array}{c}\text { Total Hutang } \\
\text { Total Aset }\end{array}$ & Rasio \\
\hline $\begin{array}{l}\left(\mathrm{X}_{2}\right) \text { Arus } \\
\text { Kas Operasi }\end{array}$ & Aliran Kas Operasi & Rasio \\
\hline $\begin{array}{l}\left.\mathrm{X}_{3}\right) \\
\text { Komponen } \\
\text { Akrual }\end{array}$ & $\begin{array}{c}\text { Laba Bersih - Aliran Kas Operasi } \\
\text { Total Aset }\end{array}$ & Rasio \\
\hline $\begin{array}{l}\text { (Y) } \\
\text { Persistensi } \\
\text { Laba }\end{array}$ & $\begin{array}{l}\text { Eit }=\beta_{0}+\beta_{1} \text { Eit- } 1+\varepsilon \text { it } \\
\text { Persistensi laba diukur menggunakan } \\
\text { koefisien regresi }\left(\beta_{1}\right) \text { antara laba akuntansi } \\
\text { pada satu perioda sekarang (Eit) dengan laba }\end{array}$ & Rasio \\
\hline
\end{tabular}




\begin{tabular}{|l|l|l|}
\hline & $\begin{array}{l}\text { akuntansi sebelum pajak perioda sebelumnya } \\
(\text { Eit-1). }\end{array}$ & \\
\hline $\begin{array}{l}\text { Corporate } \\
\text { Governance }\end{array}$ & $\begin{array}{c}\text { Total skor item yang digunakan oleh } \\
\text { Skor maksimum yang diiungkapkan oleh }\end{array}$ & Rasio \\
\hline $\begin{array}{l}\text { Ukuran } \\
\text { Perusahaan } \\
\text { (SIZE) }\end{array}$ & $\begin{array}{l}\text { Logaritma Natural dari Total Aset } \\
\text { TA } \mathrm{A}_{\mathrm{it}}=\text { Total Aktiva Perusahaan i pada tahun } \mathrm{t}\end{array}$ & Rasio \\
& & \\
\hline
\end{tabular}

\section{Metode Analisis}

Metode analisis yang digunakan dalam penelitian ini adalah regresi berganda. Data penelitian akan diuji dengan pengujian statistik menggunakan SPSS 21.

\section{Teknik Pengambilan Sampel}

kriteria pengambilan sampel dalam penelitian ini adalah sebagai berikut:

1. Perusahaan yang diteliti adalah perusahaan yang terdaftar di Bursa Efek Indonesia dan tergolong dalam industri manufaktur berdasarkan pengklasifikasian Indonesia Capital Market Directory (ICMD) periode 2010 sampai dengan 2015 .

2. Perusahaan mempublikasikan laporan keuangan auditan periode 2011 sampai dengan 2015.

3. Perusahaan tidak megalami kerugian dalam laporan keuangan selama tahun 2011-2015,

4. Perusahaan memiliki data yang lengkap untuk penelitian dan menggunakan mata uang rupiah. 


\section{Metode Analisis data}

\section{Uji Statistik Deskriptif}

Analisis statistik deskriptif digunakan untuk memberikan deskripsi atas variabel-variabel penelitian secara statistik. Menurut Sekaran dan Bougie (2013), statistik deskriptif dalam penelitian pada dasarnya merupakan proses transformasi data penelitian dalam bentuk tabulasi sehingga mudah dipahami dan diinterpretasikan.

\section{Uji Normalitas}

Pengujian normalitas dalam penelitian ini dengan menggunakan one sample kolmogorov-smirnov test dan analisis grafik histogram dan P-P plot. Dalam kolmogorov-smirnov test, menurut Ghozali (2013:160) pedoman yang digunakan dalam pengambilan keputusan adalah : Ho : Data residual berdistribusi normal dan Ha : Data residual tidak berdistribusi normal

\section{Uji Multikolinearitas}

Uji Multikolinearitas bertujuan untuk menguji apakah model regresi ditemukan adanya korelasi antar variabel bebas (independen). Model regresi yang baik seharusnya tidak terjadi korelasi diantara variabel bebas. Untuk mendeteksi ada atau tidaknya multikolonieritas di dalam model regresi dapat dilihat dari (1) nilai tolerance dan lawannya (2) Variance Inflation Factor (VIF). Nilai cutoff yang umum dipakai untuk menunjukkan adanya mutikolonieritas adalah nilai tolerance $\leq 0,10$ atau sama dengan nilai $\mathrm{VIF} \geq 10$.

\section{Uji Heteroskedastisitas}

Uji Heteroskedastisitas bertujuan untuk menguji apakah model regresi terjadi ketidaksamaan variance dari residual satu pengamatan ke pengamatan lain. Cara untuk mendeteksi ada atau tidaknya heteroskedastisitas yaitu dengan dilakukan uji glejser yaitu meregres nilai absolute residual terhadap variabel independen. Dikutip dari www.spssindonesia.com disebutkan bahwa dasar pengambilan keputusan pada uji heterokedastisitas yaitu jika nilai signifikansi lebih besar dari 0,05, kesimpulannya adalah tidak terjadi heterokedastisitas, dan Jika nilai signifikansi lebih kecil dari 0,05, kesimpulannya adalah tidak terjadi heterokedastisitas 


\section{Uji Autokorelasi}

Pengujian autokorelasi pada penelitian ini menggunakan uji DurbinWatson (DW test). Pengambilan keputusan ada tidaknya autokorelasi adalah sebagai berikut :

a) Bila nilai DW terletak antara batas atas (du) dan (4-du), maka koefisien autokorelasi sama dengan nol berarti tidak ada autokorelasi;

b) Bila nilai DW lebih rendah dari pada batas bawah (di), maka koefisien autokorelasi lebih dari nol berarti ada autokorelasi positif;

c) Bila nilai DW lebih dari pada (4-dl), maka maka koefisien autokorelasi lebih kecil dari nol berarti ada autokorelasi negatif;

d) Bila nilai DW terletak antara batas atas (du) dan batas bawah (dl) atau DW, maka hasilnya tidak dapat disimpulkan.

\section{Pengujian Hipotesis}

\section{Model persamaan regresi berganda}

Metode yang digunakan untuk pengujian hipotesis dalam penelitian ini adalah analisis regresi berganda yang bertujuan untuk mengukur kekuatan hubungan antara dua variabel atau lebih, selain itu juga menunjukkan arah hubungan antara variabel dependen dengan variabel independen. Untuk menguji tingkat hutang, arus kas, akrual terhadap persistensi laba dengan corporate governance sebagai variabel moderating dan ukuran perusahaan sebagai variabel control yaitu dengan menggunakan persamaan sebagai berikut:

\section{$\mathrm{PL}=\beta \beta_{0}+\beta_{1} \mathrm{HT}+\beta_{2} \mathrm{CFO}+\beta_{3} \mathrm{ACC}+\beta_{4} \mathrm{HT} * \mathrm{CG}+\beta_{5} \mathrm{CFO} * \mathrm{CG}+\beta_{6} \mathrm{ACC} * \mathrm{CG}+$ $\beta_{7} \mathrm{SIZE}+\mathrm{e}$}

Keterangan:

PL = Persistensi Laba;

$\beta o=$ Konstanta;

$\beta_{1}, \beta_{2} \ldots \beta_{8}=$ Koefisien Regresi dari masing-masing variabel bebas;

HT= Tingkat Hutang

$\mathrm{CFO}=$ CashFlow Operation

$\mathrm{ACC}=$ Accrual 
$\mathrm{CG}=$ Corporate Governance

SIZE = Ukuran Perusahaan

Hipotesis statistik dalam pengujian ini adalah:

Hipotesis 1 , jika $\beta 1>0$

Hipotesis 2, jika $\beta 2>0$

Hipotesis 3, jika $\beta 3<0$

Hipotesis 4, jika $\beta 4>0$

Hipotesis 5, jika $\beta 5>0$

Hipotesis 6, jika $\beta 6<0$

\section{Pembahasan}

\section{Deskripsi Obyek Penelitian}

Populasi dalam penelitian ini adalah perusahaan industri manufaktur go public yang terdaftar di Bursa Efek Indonesia (BEI) mulai tahun 2011-2015. Meskipun rentang waktu yang digunakan mulai dari tahun 2011, namun data keuangan yang digunakan seluruhnya dalam penelitian ini mulai dari tahun 2005 hingga 2015.

\section{Analisis Hasil Penelitian}

Tabel 4.2

Statistik Deskriptif

\begin{tabular}{|l|r|r|r|r|r|}
\hline & N & Minimum & Maximum & Mean & \multicolumn{1}{c|}{$\begin{array}{c}\text { Std. } \\
\text { Deviation }\end{array}$} \\
\hline PL & 210 & 0,06 & 1,50 & 0,70 & 0,35 \\
HT & 210 & 0,07 & 0,88 & 0,41 & 0,17 \\
CFO & 210 & $-0,16$ & 0,66 & 0,12 & 0,12 \\
ACC & 210 & $-0,18$ & 0,25 & $-0,02$ & 0,07 \\
CG & 210 & 0,03 & 0,86 & 0,57 & 0,15 \\
SIZE & 210 & 18,39 & 26,19 & 21,64 & 1,70 \\
Valid N (listwise) & 210 & & & & \\
\hline
\end{tabular}

Sumber: Hasil output SPSS 


\section{Uji Normalitas}

Hasil pengujian normalitas model dapat dilihat pada gambar 4.3, hasil uji normalitas Kolmogorov-Sminov diperoleh Asymp. Sig (2-tailed) 0,334 lebih besar dari kriteria normal 0,05 yang berarti bahwa data berdistribusi normal.

Tabel 4.3

\section{Hasil Uji Normalitas Kolmogorov-Sminov}

One-Sample Kolmogorov-Smirnov Test

\begin{tabular}{|c|c|c|}
\hline & & $\begin{array}{l}\text { Unstandardi } \\
\text { zed Residual }\end{array}$ \\
\hline \multirow[t]{2}{*}{$\mathrm{N}$} & & 210 \\
\hline & Mean & 0,0000000 \\
\hline \multirow[t]{3}{*}{ Normal Parameters ${ }^{\mathrm{a}, \mathrm{b}}$} & Std. & 0,33099768 \\
\hline & Deviation & \\
\hline & Absolute & 0,065 \\
\hline \multirow[t]{2}{*}{ Most Extreme Differences } & Positive & 0,065 \\
\hline & Negative & $-0,063$ \\
\hline Kolmogorov-Smirnov Z & & 0,945 \\
\hline Asymp. Sig. (2-tailed) & & 0,334 \\
\hline
\end{tabular}

Sumber: Hasil output SPSS

\section{Uji Multikolinieritas}

pada tabel 4.4 terdapat sebagian variabel yang menghasilkan nilai VIF>10 yang artinya multikolinearitas terjadi pada variabel arus kas, akrual, variabel independen arus kas yang dimoderasi dengan corporate governance, dan variabel independen akrual yang dimoderasi dengan corporate governance

\section{Tabel 4.4}

\section{Hasil Pengujian Multikolinieritas}

\begin{tabular}{|l|r|r|l|}
\hline \multirow{2}{*}{ Model } & \multicolumn{2}{|c|}{ Collinearity Statistics } & Keterangan \\
\cline { 2 - 3 } & Tolerance & \multicolumn{1}{c|}{ VIF } & \\
\hline HT & 0,167 & 5,996 & Tidak terjadi multikolinieritas \\
CFO & 0,025 & 40,148 & Terjadi Multikolinieritas \\
\hline
\end{tabular}




\begin{tabular}{l|r|r|l|} 
ACC & 0,036 & 27,778 & Terjadi Multikolinieritas \\
CG_HT & 0,127 & 7,870 & Tidak terjadi multikolinieritas \\
CG_CFO & 0,022 & 44,481 & Terjadi Multikolinieritas \\
CG_ACC & 0,038 & 26,164 & Terjadi Multikolinieritas \\
SIZE & 0,776 & 1,288 & Tidak terjadi multikolinieritas \\
\hline
\end{tabular}

Sumber : Data sekunder yang diolah, 2016

\section{Uji Heteroskedastisitas}

Hasil uji heteroskedastisitas dapat dilihat juga pada tabel 4.5 yaitu semua variabel memiliki tingkat signifikan diatas atau lebih besar dari 0,05, maka kesimpulannya adalah tidak terjadi heteroskedastisitas. Berdasarkan hasil pengujian terhadap data yang diperoleh, maka didapatkan hasil sebagai berikut :

Tabel 4.5

\section{Hasil Pengujian Heterokedastisitas}

\section{Uji Autokorelasi}

\begin{tabular}{|l|r|r|}
\hline Model & \multicolumn{1}{c|}{ Sig. } & \multicolumn{1}{c|}{$\begin{array}{c}\text { Sig. } \\
\text { (1- tailed })\end{array}$} \\
\hline HT & 0,421 & 0,211 \\
CFO & 0,943 & 0,471 \\
ACC & 0,790 & 0,395 \\
CG_HT & 0,300 & 0,150 \\
CG_CFO & 0,674 & 0,337 \\
CG_ACC & 0,921 & 0,461 \\
SIZE & 0,541 & 0,271 \\
\hline
\end{tabular}

Berdasar hasil analisis regresi diperoleh nilai D-W sebesar 1.979, nilai ini dibandingkan denngan nilai tabel signifikansi 5\%, jumlah sampel 210 (n) sedang nilai du diperoleh sebesar 1,760 dan dam 4-du sebesar 2.240. Dengan demikian diperoleh bahwa nilai DW berada diantara dU yaitu 1,757 dan 4 - du yaitu 2,240. Dengan demikian menunjukkan bahwa model regresi tersebut sudah bebas dari masalah autokorelasi.

\section{Tabel 4.6}


Hasil Uji Autokorelasi

\begin{tabular}{|l|r|}
\hline Model & Durbin-Watson \\
\hline 1 & 1.979 \\
\hline
\end{tabular}

\section{Hasil Uji Koefisien Determinasi $\left(\mathbf{R}^{2}\right)$}

Dari pengujian pada data diperoleh hasil sebagai berikut:

Tabel 4.7

Hasil Uji $\mathbf{R}^{2}$

\begin{tabular}{|l|r|r|r|}
\hline Model & \multicolumn{1}{|c|}{ R } & \multicolumn{1}{|c|}{ R Square } & \multicolumn{1}{|c|}{ Adjusted R Square } \\
\hline 1 & $0,360^{\mathrm{a}}$ & 0,130 & 0,099 \\
\hline
\end{tabular}

Pada tabel 4.7 hasil pengujian menunjukan bahwa koefisien korelasi (R), koefisien determinasi ( $\mathrm{R}$ Square) dan koefisien determinasi yang disesuaikan(adjusted R). Dari tabel 4.7 di atas terlihat bahwa koefisien determinasi yang disesuaikan (Adjusted R Square) sebesar adalah 0.099. hal tersebut berarti bahwa 9,9\% variabel persistensi laba (PL) dapat dijelaskan oleh variabel tingkat hutang, arus kas operasi, akrual dan variabel moderating corporate governance.

\section{Hasil Uji Statistik F}

Dari hasil uji ANOVA atau F test pada tabel 4.8, F hitung untuk ketika model tersebut menghasilkan tingkat signifikansi sebesar 0.000 . Karena probabilitasnya (0.000) jauh lebih kecil dari 0.05 , maka model regresi bisa dipakai untuk memprediksi persistensi laba.

Tabel 4.8

Hasil Uji F

\begin{tabular}{|c|c|c|c|c|c|c|}
\hline \multicolumn{2}{|c|}{ Model } & Sum of Squares & $\overline{\mathrm{df}}$ & Mean Square & $\bar{F}$ & Sig. \\
\hline & Regression & 3,399 & 7 & 0,486 & 4,299 & $0,000^{\mathrm{b}}$ \\
\hline 1 & Residual & 22,815 & 202 & 0,113 & & \\
\hline & Total & 26,214 & 209 & & & \\
\hline
\end{tabular}


a. Dependent Variable: PL

b. Predictors: (Constant), SIZE, HT, CG_ACC, CG_CFO, CG_HT, ACC,

CFO

\section{Pembahasan Hasil Penelitian}

Tabel 4.9

Hasil Pengujian Hipotesis

\begin{tabular}{|l|c|r|r|r|r|l|}
\hline \multicolumn{1}{|c|}{ Model } & Prediksi & \multicolumn{1}{c|}{ B } & \multicolumn{1}{c|}{ T } & \multicolumn{1}{c|}{ Sig. } & \multicolumn{1}{c|}{ Sig. } & Kesimpulan \\
& & & & & & \\
\hline Constant tailed $)$ & \\
HT & & 0,790 & 2,331 & 0,021 & 0,010 & \\
CFO & + & $-0,478$ & $-1,425$ & 0,156 & 0.078 & H1 Ditolak \\
ACC & + & 3,073 & 2,592 & 0,010 & 0,050 & H2 Diterima \\
CG_HT & + & 3,216 & 1,851 & 0,066 & 0,033 & H3 Ditolak \\
CG_CFO & + & 1,080 & 1,890 & 0,060 & 0,003 & H4 Ditolak \\
CG_ACC & - & $-3,033$ & $-1,673$ & 0,096 & 0,048 & H5 Ditolak \\
SIZE & & $-0,013$ & $-0,858$ & 0,392 & 0,196 & H6 Ditolak \\
& & & & & & \\
\hline
\end{tabular}

Tingkat hutang berpengaruh positif siginifikan terhadap persistensi laba.

Hasil penelitian ini belum dapat membuktikan bahwa tingkat hutang berpengaruh terhadap persistensi laba. Secara teori dinyatakan bahwa perusahaan yang akan melakukan ekspansi dengan modal kerja yang dibiayai oleh pinjaman atau hutang cenderung akan meningkatkan laba untuk mempertahankan kinerja yang baik dimata investor. Pada tabel 4.9 dapat dilihat hasil pengujian membuktikan bahwa tingkat hutang tidak berpengaruh terhadap persistensi laba, sehingga hipotesis pertama ditolak. Hasil tersebut mendukung penelitian Suwandika danAstika (2013) Nurochman daan Solikhah (2015) Kusuma dan Sadjiarto (2014) yang menyatakan bahwa tingkat hutang berpengaruh negatif signifikan pada persistensi laba. 


\section{Arus kas berpengaruh positif siginifikan terhadap persistensi laba.}

Pada tabel 4.9 dapat dilihat hasil pengujian membuktikan bahwa arus kas berpengaruh positif signifikan terhadap persistensi laba, dengan demikian hipotesis diterima, hal ini mengisyaratkan bahwa semakin tinggi komponen arus kas maka akan meningkatkan persistensi laba yang dimiliki oleh perusahaan. Hasil pengujian ini konsisten dengan penelitian yang dilakukan oleh Dewi dan putri (2015), Asma (2013), serta Barus dan Rica (2015) yang membuktikan arus kas operasi berpengaruh positif terhadap persistensi laba.

\section{Akrual berpengaruh negatif siginifikan terhadap persistensi laba.}

Pada tabel 4.9 dapat dilihat akrual (ACC) menunjukkan koefisien regresi positif sebesar 3,216 dengan tingkat signifikansi sebesar 0,033 lebih kecil dari $\alpha=$ 0,05, hasil pengujian ini tidak dapat membuktikan bahwa akrual berpengaruh negatif terhadap persistensi laba, sehingga hipotesis ketiga ditolak. Hasil pengujian ini tidak dapat membuktikan penelitian terdahulu yang dilakukan Oei et.all (2008) dan Fanani (2010) yang membuktikan accrual berpengaruh negatif signifikan. Fanani (2010) menunjukkan besaran akrual memiliki hubungan negatif terhadap persistensi laba, hal ini disebabkan meskipun seberapa kecilnya komponen akrual yang terjadi di perusahaan akan menyebabkan gangguan (noise) yang dapat mengurangi persistensi laba.

\section{Corporate Governance memperkuat hubungan positif antara tingkat hutang terhadap persistensi laba.}

Pada tabel 4.9 dapat dilihat hasil pengujian menunjukkan koefisien regresi positif sebesar 1,080 dengan tingkat signifikansi sebesar 0,030 lebih kecil dari $\alpha=$ 0,05, walaupun nilai koefisiennya positif, tetapi uji pengaruh tingkat hutang terhadap persistensi laba menunjukan tidak berpengaruh terhadap persistensi laba, hal ini berarti corporate governance tidak dapat memoderasi hubungan tingkat hutang terhadap persistensi laba. Hasil penelitian ini tidak dapat membuktikan bahwa corporate governance (CG) memperkuat hubungan positif antara tingkat hutang terhadap persistensi laba, dah hipotesis ke empat ditolak. 
Menurut Khafid (2012) dan Irfan (2014) corporate governance berpengaruh terhadap persistensi laba. Berpengaruhnya corporate governance pada persistensi laba dalam penelitian ini terjadi karena unsur-unsur dari corporate governance di dalam perusahaan telah dilaksanakan dengan baik. Kemungkinan hutang telah dikelola dengan baik dan efisien serta transparan tetapi tidak berpengaruh terhadap persistensi laba, karena manajer perusahaan cenderung akan melakukan kinerja yang sama dengan tingkat hutang yang tinggi maupun tingkat hutang yang rendah.

Corporate Governance memperkuat hubungan positif antara Arus Kas terhadap persistensi laba.

Pada tabel 4.9 dapat dilihat hasil pengujian menunjukkan koefisien regresi negatif sebesar -3,033 dengan tingkat signifikansi sebesar 0,048 lebih kecil dari $\alpha=$ 0,05, hal ini berarti pengaruh corporate governance tidak dapat memoderasi hubungan positif antara arus kas terhadap persistensi laba. Hasil penelitian ini tidak dapat membuktikan bahwa corporate governance (CG) dapat memperkuat hubungan positif antara arus kas terhadap persistensi laba, dan hipotesis ke lima ditolak.

Arus kas operasi merupakan transaksi riil yang tidak dapat dimanipulasi, namun penerapan corporate governance tidak dapat memoderasi hubungan positif antara arus kas operasi dengan persistensi laba. Pengaruh negatif corporate governance dimungkinkan karena dalam penelitian ini unsur corporate governance melibatkan faktor internal dan eksternal dalam penilaian menggunakan ACGS yang belum dapat diimplementasikan secara keseluruhan.

\section{Corporate Governance memperkuat hubungan negatif antara Akrual terhadap persistensi laba.}

Berdasarkan tabel 4.9 menunjukkan koefisien regresi negatif sebesar -3,470 dengan tingkat signifikansi sebesar 0,119 lebih besar $\alpha=0,05$. Hasil penelitian ini tidak dapat membuktikan bahwa corporate governance dapat memperlemah hubungan negatif antara akrual terhadap persistensi laba, dan hipotesis ke enam ditolak. 
Pengaruh corporate governance negatif berarti menunjukan bahwa penerapan corporate governance dapat menghambat akitivitas rekayasa kinerja terutama dalam hal transaksi akrual, manajemen menyajikan informasi keuangan dengan full disclosure, namun hasil uji ini menunjukan bahwa corporate governance tidak dapat memoderasi hubungan antara akrual dan persistensi laba karena corporate governance atas tanggungjawab dewan yang diukur dengan ACGS yang kurang berpengaruh. Penelitian tersebut tidak dapat membuktikan bahwa Alhamra dan hermiyetti (2016) yang secara simultan GCG mempunyai pengaruh terhadap pengunkapan informasi akuntansi dan penelitian Juwatiningsih (2014), Ikhsan (2014) dan Khafid (2012) membuktikan bahwa corporate governance berpengaruh terhadap persistensi laba.

\section{SIMPULAN}

Berdasarkan hasil analisis dan pembahasan pada bab sebelumnya, maka dapat diperoleh kesimpulan penelitian sebagai berikut:

1. Tingkat hutang tidak berpengaruh terhadap persistensi laba.

2. Arus kas berpengaruh positif signifikan terhadap persistensi laba.

3. Akrual tidak berpengaruh negatif terhadap persistensi laba.

4. Corporate governance tidak terbukti memperkuat hubungan positif antara tingkat hutang dan persistensi laba.

5. Corporate governance tidak terbukti memperkuat hubungan positif antara arus kas dan persistensi laba.

6. Corporate governance tidak terbukti memperlemah hubungan negatif antara akrual dan persistensi laba.

\section{DAFTAR PUSTAKA}

Anton, Fx. (2010). Menuju Teori Stewardship Manajemen. Majalah Ilmiah Informatika, Vol. 1, No. 2

Asma,T.N. (2013). Pengaruh Aliran Kas Dan Perbedaan Antara Laba Akuntansi Dengan Laba Fiskal Terhadap Persistensi Laba. Jurnal Akuntansi. Vo. 1 No.1 
Barus, A.C, dan V. Rica. (2014). Analsiis faktor-faktor yang mempengaruhi persistensi laba. Jurnal Wira Ekonomi Mikroskil. Vol.4 N0.2.

Boediono, G.S.B, (2005). Kualitas Laba: Studi Pengaruh Mekanisme Corporate Governance dan Dampak Manajemen Laba Dengan Menggunakan Analisis Jalur. Makalah disajikan dalam Simposium Nasional Akuntansi VIII. Surakarta.

Chandrarin, G, (2003). “The Impact of Accounting Methods For Transaction Gains (Losses) on The Earnings Response Coefficient : The Indonesian Case", Jurnal Riset Akuntansi Indonesia. Vol. 6, No 3, September : 217-231.

Dechow P. dan I. Dichev.,(2002). The Quality of Accruals and Earning: The Role of Accrual Estimation Errors. The Accounting Review 77. Suplement: 3559.

Dechow, P. M \& Ge, W. (2006). The Persistence of Earnings and Cash Flows and the Role of Special Items. Implications for the Accrual Anomaly. Vol. 11: 253-296

Dewi, L., dan A.D. Putri, (2015)., Pengaruh Book-Tax Difference, Arus Kas Operasi, Arus Kas Akrual, Dan Ukuran Perusahaan Pada Persistensi Laba. E-Jurnal Akuntansi Universitas Udayana.10.1, 244-260, ISSN: 23028556.

Dridi, W., dan B. Adel, (2016). Book-Tax Differences and the Persistence of Earnings and Accruals: Tunisian Evidence. Asian Social Science; Vol. 12, No. 6.

Dridi.W., (2015). Corporate Governance and Book Tax Differences : Tunisian Evidence.International Journal of Economics and Finance, Vol. 8, No. 1.

Fanani, Z., (2010). Analisis Faktor-Faktor Penentu Persistensi Laba, Jurnal Akuntansi dan Keuangan Indonesia, Vol 7, No. 1 :109-123.

Fanani,Z., (2009), Kualitas Pelaporan Keuangan: berbagai Faktor Penentu dan Konsekuensi Ekonomis.Jurnal Akuntansi dan Keuangan Indonesia, Vol. 6, No.1

Fitriyani, D., W. Tiswiyanti, E. Prasetyo. (2015). Praktik Good Corportae Governance Dan Dampaknya Terhadap Kinerja Berdasarkan Balance Scorecard. Conference In Business, Accounting and Management. Vol. 2. No. 1 
Francis, J., R. LaFond, P. Olsson, and K. Schipper. (2004). Costs of Equity and Earnings attributes. The Accounting Review, 79 (4) : 967-1010.

Gandasari, I dan Herawaty,V. (2015). Pengaruh Karakteristik perusahaan terhadap Perataan Laba Dengan Good Corporate Governance Sebagai variabel Moderasi. Jurnal Magister Akuntansi Trisakti. Vol.2, No.1 :73-94. ISSN:2339-0859.

Ghozali., Imam. (2013). Aplikasi Analisis Multivariate dengan Program SPSS, Badan Penerbit Universitas Dipenegoro Semarang.

Herawati, V., (2008) Peran Praktek Corporate Governance Sebagai Moderating Variable dari Pengaruh Earnings Management Terhadap Nilai Perusahaan.. Jurnal Akuntamsi dan Keuangan., Vo.10, No.2.

Ikatan Akuntan Indonesia. (2015). Standar Akuntansi Keuangan. Jakarta Salemba Empat.

Ikhsan, T., (2014). Pengaruh Kualitas Penerapan Corporate Governance dan Konsentrasi Kepemilikan Terhadap Perisistensi Laba. Jurnal Ekonomi Dan Bisnis, Vol. 11 No.2.

Junawatiningsih, T. Dan P.Harto. (2014). Analisis Pengaruh Mekanisme Internal dan Eksternal Corporate Governance Terhadap Persistensi Laba. Dipenogoro Journal Of Accounting.Vol. 3, No. 4 : 1-11

Kusuma,H. (2005). Size Perusahaan dan Profitabilitas. Jurnal Ekonomi Pembangunan, Vol. 10, No. 1: 81 - 93.

Kusuma, B. dan R.A. Sadjiarto, (2014), Analisa Pengaruh Volatilitas Arus Kas, Volatilitas Penjualan, Tingkat Hutang, Book Tax Gap, dan Tata Kelola Perusahaan Terhadap Persistensi Laba. Tax\&Accounting Review, Vol.4, No.1.

Khafid, .M., (2012). Pengaruh Tata Kelola Perusahaan (Corporate Governance) Dan Struktur Kepemilikan Terhadap Persistensi Laba. Jurnal Dinamika Akuntansi, Vol.4, No.2 : 139-148.

Linda., L. Mayarsih dan Nuraini, (2011). Komite Audit dan Kinerja perusahaan Agency Teory atau Stewardship Theory. Simposium nasional Akuntansi $X I V$.

Nurochman, A. dan B. Solikhah. (2015). Pengaruh Good Corporate Governance, Tingkat Hutang dan Ukuran Perusahaan Terhadap Persistensi Laba. Accounting Analysis Journal Vol 4 No. 4. 
Oei, R., A. Ramsay,P. Mather, (2008). Earnings persistence, accruals and managerial share ownership. Accounting and Finance 48, 475-502.

Pagalung, Gagaring., and Bambang Sudibdyo., 2009. The Determinant Factors of Earning Quality and Economic Consequences. Jurnal Ekonomi dan Keuangan, Vol.16: 105-122.

Perman, S.H. (2001). On Comparing Cash Flow And Accrual Accounting Models For Use In Equity Valuation. Working paper. www.ssm.com.

Penman, S.H. dan Zang (2002). Financial Statement Analysis and Security Valuation. Second Editon: McGraw Hill.

Sadiah, H. (2015). Pengaruh Leverage, Likuiditas, Size, Pertumbuhan Laba dan Ios Sawir, Agnes, (2009). Analisa Kinerja Keuangan dan Perencanaan keauangan Perusahaan, PT. Gramedia Pustaka Utama, Jakarta.

Schipper, K. and L. Vincent. (2003). Earnings Quality. Accounting Horizons, 70 (Supplement), 97-110.

Scot, W. (2015) Financial Accounting Theory provides a thorough presentation of financial accounting theories. 7 Ed.Pearson.

Sin.M.N., (2012), Pengaruh Large Book Tax diffrences Terhadap Persistensi Laba, Akrual dan Arus Kas pada perusahaan di BEI.Jurnal Ilmiah mahasiswa Akuntansi, Vol.1, No.4.

Surifah, (2010). Persistensi laba dan Pengukurannya. Jurnal Ekonomi,Manajemen \& Akuntansi, Vol. 8, No. 2.

Subramanyan.K.R. dan J.J. Wild, (2013). Analisis Laporan Keuangan. Salemba Empat. Edisi 10.

Sunarto, (2009), Teori Keagenan dan Manajemen Laba, Kajian Akuntansi, Hal 1328, ISSN:1979-4886

Sunarto, (2010), Peran Persistensi Laba Terhadap Hubungan Antara Keagresifan Laba dan Biaya Ekuitas. Vo;.2 No.1

Suwadjono. (2005). Teori Akuntansi : Perekayasaan Pelaporan Keuangan. Edisi ketiga ISBN:979-503-478-2. Penerbit BPFE Yogyakarta.

Suwandika, I Made Andi dan Ida Bagus PutraAstika. (2013). Pengaruh Perbedaan Labaakuntansi,Laba Fiskal, Tingkat Hutang Pada Persistensi Laba. EJurnal Akuntansi Universitas Udayana Vol.5, No.1: 196-214. 
Wijayanti, Handayani Tri. (2006). Analisis Pengaruh Perbedaan Antara Laba Akuntansi dan Laba Fiskal terhadap Persistensi Laba, Akrual, dan Arus Kas. Prosiding Simposium Nasional Akuntansi IX, Padang. 